\title{
Prevalence of asbestos bodies in a necropsy series in East London: association with disease, occupation, and domiciliary address
}

\author{
I. DONIACH, K. V. SWETTENHAM, and M. K. S. HATHORN \\ Departments of Morbid Anatomy and Physiology, The London Hospital Medical College, \\ London El 1BB
}

Doniach, I., Swettenham, K. V., and Hathorn, M. K. S. (1975). British Journal of Industrial Medicine, 32, 16-30. Prevalence of asbestos bodies in a necropsy series in East London: association with disease, occupation, and domiciliary address. The prevalence of asbestos bodies was measured in lung sections in a necropsy series carried out at the London Hospital (1965-66) after exclusion of all known asbestos factory workers and cases of asbestosis and of mesothelioma. Associations were sought between the presence and number of asbestos bodies with the patients' sex, domiciliary address, occupation, industry, and diseases recorded at necropsy. Asbestos bodies were present in $42 \%$ of the 216 men in the series and in $30 \%$ of the 178 women. The number of bodies in the positive cases was small in comparison with the numbers seen typically in asbestosis; thus there were less than 6 asbestos bodies per 6.75 $\mathrm{mm}^{3}$ lung tissue in 107 of the total 145 positive cases in contrast to 1000 or more in asbestosis. In comparison with the overall series, an increased number of asbestos body positives was present in males with carcinoma of stomach and females with carcinoma of breast. In view of this finding lung sections were counted in further post-mortem examples of these carcinomas making a total of 50 males with carcinoma stomach and 82 females with carcinoma breast. Thirty-five positive cases were found in the carcinoma stomach group as against 22.7 expected and 38 in the carcinoma breast group against $26 \cdot 35$ expected. There was no excess of observed over expected asbestos body positives in 51 males with carcinoma of bronchus.

There was an excess of asbestos body positives $(60.9 \%$ ) in heavy manual workers and in both heavy and light manual male workers in the shipping (61\%), electrical and engineering $(56 \%)$, and transport $(54 \%)$ industries. The incidence in male clerical workers was $12.8 \%$. The incidence of asbestos body positives according to home address was highest $(53 \%$ in males, $45 \%$ in females) in patients living in the industrial and dockland area due east of the hospital. The incidence fell in the less industrial areas north-east of the hospital. Consideration of possible environmental sources of the inhaled asbestos suggests that in this survey occupation, industry, and domiciliary area all play a part. The comparatively minor intensity of asbestos pollution in our positive cases showed a positive association with carcinoma of stomach and breast, possibly playing a direct pathogenic role in carcinoma of stomach. No positive association was identified with any other neoplastic disease including carcinoma of bronchus. 
The high prevalence of asbestos bodies in postmortem lungs in many countries has been documented many times (Selikoff and Hammond, 1970). The object of the present study was to investigate possible associations of the presence of asbestos bodies with any of the major disease processes present in a consecutive series of necropsies, excluding all patients known to have been asbestos factory workers, all cases of asbestos pneumoconiosis (asbestosis), and all patients with mesothelioma. It is known that asbestos workers have a raised incidence of carcinoma of bronchus and possibly of the gastrointestinal tract (Elmes and Simpson, 1971). We were interested to see whether people without pulmonary asbestosis but positive for asbestos bodies show a raised incidence of these malignancies. It was also considered worthwhile to seek any association of prevalence of asbestos bodies with occupation and domiciliary address.

\section{Materials and methods}

The material was derived from consecutive routine necropsies done at The London Hospital between September 1965 and December 1966. An extra block of lung was taken from the base of the left lower lobe, fixed in formal saline, embedded in paraffin wax, and sectioned at $30 \mu$. The sections were deparaffinized and mounted unstained in Canada balsam. The total number of asbestos bodies was counted in a $1.5 \mathrm{~cm}$ square delineated by a mask placed over the cover-slip (i.e., $6.75 \mathrm{~cm}^{3}$ of lung tissue). The sections were screened with a $\times 16$ objective and asbestos bodies were confirmed using a $\times 40$ objective. Dubious bodies and fragments of bodies were not counted. In the first 76 positive cases counted, the nature of the asbestos bodies was confirmed by reexamination after incineration for 30 minutes at $605^{\circ} \mathrm{C}$, which revealed their birefringent central fibre-core. The counts were done without knowledge of the clinical and post-mortem findings by one observer (K.V.S.).

The following groups of patients were deliberately excluded from the investigation: cases showing microscopic evidence of asbestos pneumoconiosis (3), cases of mesothelioma (3), and all patients under 16 years of age (69). A further group of 12 cases were excluded due to inadvertent failure to take an extra block of lung tissue. There remained a total of 394 patients, 216 men and 178 women. Calculations of statistical probability $P$ were all based on the $\chi^{2}$ test.

A proforma detailing data obtained from the clinical and post-mortem records together with asbestos body counts was designed for transcription to computer cards (Fig. 1). The patients' home addresses were marked by pins on a map of London and its environs (Fig. 2); different colours were used to represent positives and negatives for asbestos bodies. It is seen in Fig. 2 that the majority $(80 \%)$ of the home addresses of our 394 cases are in a wedge whose apex is the London Hospital, whose base follows the line of the Thames eastwards and whose upper border runs north-east out into Essex. The areas due east are mixed industrial and domiciliary, include dockland and the site of the Cape Asbestos
Factory in Barking (Fig. 2), opened in 1913 and closed in 1967. The northerly part of the wedge contains both residential districts and light industries. The further away from the apex, the more residential or rural is the district.

\section{Results}

\section{Overall prevalence of asbestos bodies}

These were identified in 91 of the 216 men $(42 \%)$ and in 54 of the 178 women $(30 \%)$. The distribution of numbers of asbestos bodies per case among the positives (Table 1) shows that the proportion of cases with 6 or more bodies per $1.5 \mathrm{~cm}^{2}$ lung section is twice as great in men as in women-29 out of 91 men, 9 out of 54 women.

TABLE 1

\section{Distribution of Asbestos Body Counts in Positive CASEs}

\begin{tabular}{c|cc}
\hline $\begin{array}{c}\text { Number of } \\
\text { asbestos bodies }\end{array}$ & $\begin{array}{c}\text { Number of } \\
\text { men }\end{array}$ & $\begin{array}{c}\text { Number of } \\
\text { women }\end{array}$ \\
\hline 1 & 24 & 21 \\
2 & 19 & 12 \\
3 & 10 & 7 \\
4 & 6 & 4 \\
5 & 3 & 1 \\
$1-5$ & 62 & 45 \\
$6-10$ & 11 & 5 \\
$11-20$ & 8 & 2 \\
21 plus & 10 & 54 \\
\hline
\end{tabular}

The distribution of cases positive for asbestos bodies according to sex and major disease process is summarized in Table 2.

In men there is no evidence of any increased incidence of asbestos positive cases when all neoplasms are grouped together. The slightly increased percentage of asbestos positive cases in women with neoplastic disease and decreased percentage in women without neoplastic disease is statistically not significant $(P=0 \cdot 5)$. The numbers of cases in many of the subgroups are too small for correlations to be made, but some are sufficient to warrant analysis. Though suggestive, the $47 \%$ incidence of positive cases in the 51 males with carcinoma of bronchus proves to be not significantly different from the overall average incidence of $42 \%(\mathrm{P}=0.5)$. Though the figures for gastric neoplasms are small they indicate a positive correlation with incidence of asbestos bodies: 8 positives out of 11 males, and 3 out of 6 females. The figures for breast carcinoma, $34 \%$ positives out of 32 women, are also slightly suggestive of a positive correlation. The findings in lymphoma show no positive correlation in males 


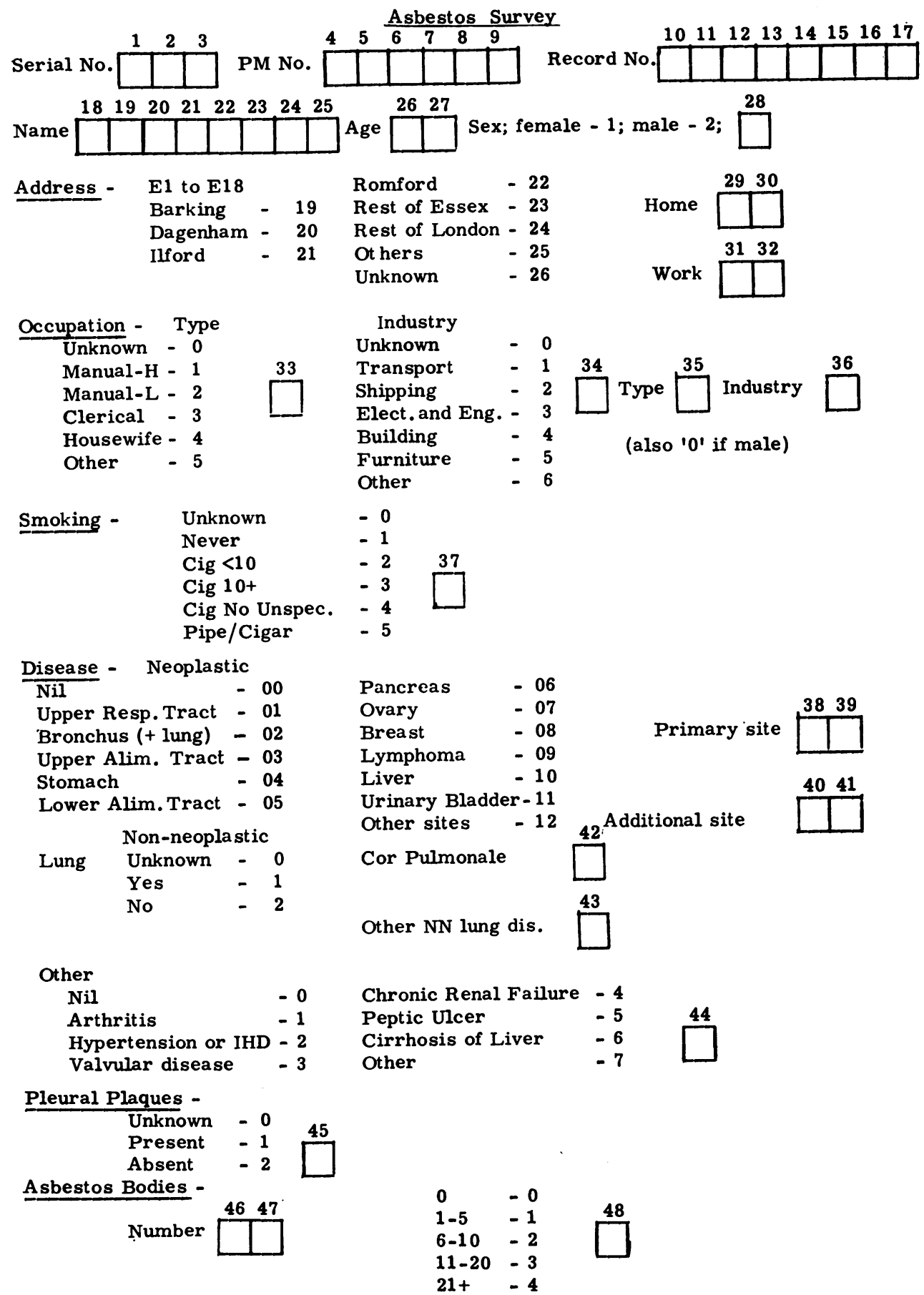

FIG. 1. Proforma used showing the data abstracted from the clinical and post-mortem records to study various possible associations with pulmonary asbestos bodies. 


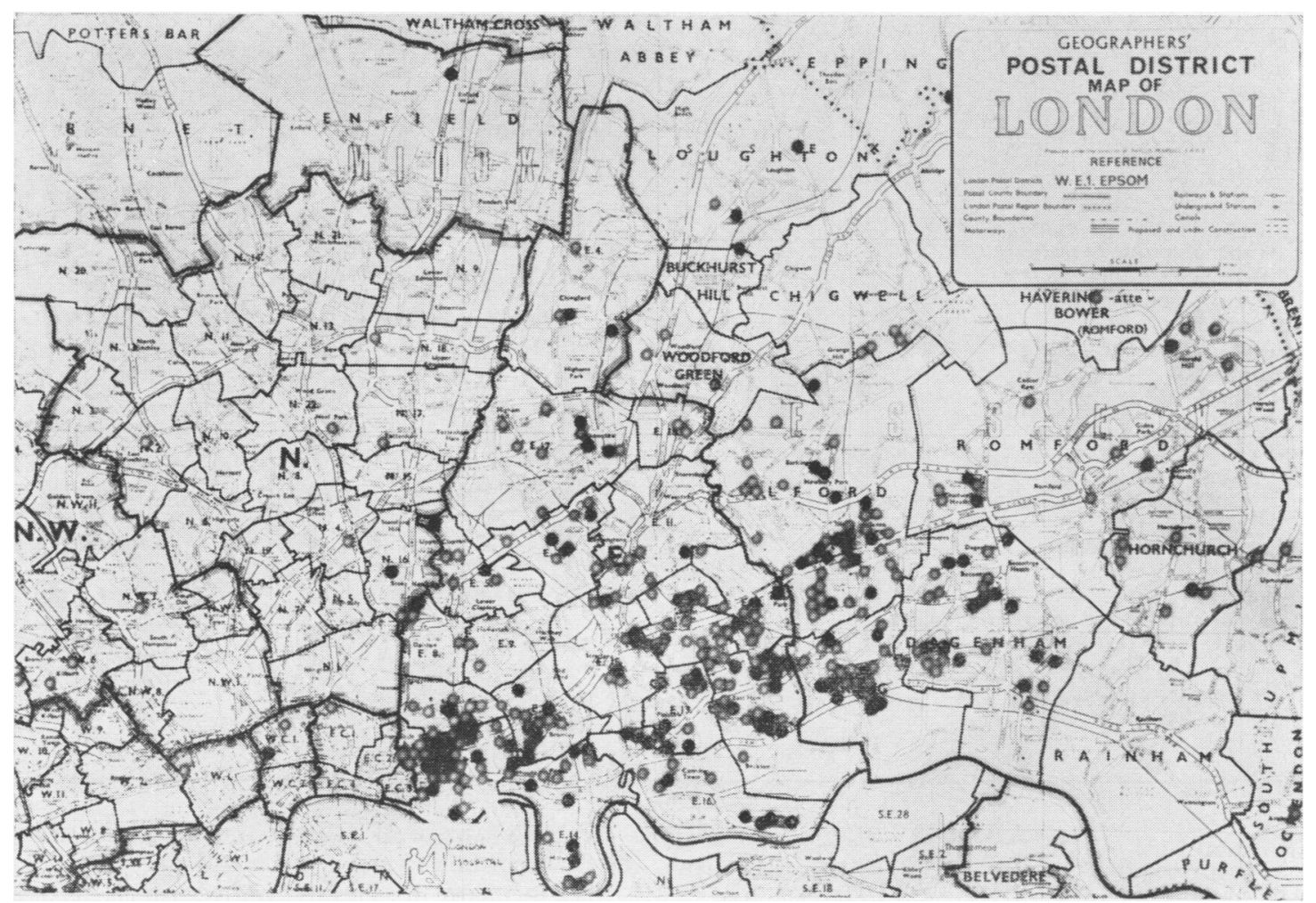

FIG. 2. Map of London showing addresses of the patients (male and female) in the necropsy series, marked by headed pins. The dark dots indicate asbestos body positive cases, the pale dots asbestos body negatives. The vast majority of the patients lived in East and North-east suburbs. (Crown Copyright reserved-Reproduced by permission of Geographers' A-2 Map Co. Ltd.)

( $31 \%$ positive) but indicate a positive correlation in females, 5 positives in 14 cases (36\%).

In view of the above findings $30 \mu$ lung sections from a further series of cases of gastric carcinoma in males and of breast carcinoma in females were examined quantitatively for the presence of asbestos bodies. The cases were taken from the years immediately preceding and succeeding the original series. The lung sections were made from blocks taken routinely and asbestos bodies were counted in a $1.5 \mathrm{~cm}^{2}$ area as described above. The results are shown in Table 3.

It is seen (Table 3) that there is a definite excess incidence of asbestos body positives in both carcinoma stomach in males $(\mathrm{P}<0.0005)$ and in carcinoma breast $(P=0.025)$. The five positive cases in the 14 women with lymphoma $(36 \%)$ proved a heterogeneous mixture of conditions. A further series was not examined.

Comparison of the numbers of asbestos bodies per case was made between the positives in the original series as a whole, the 24 positive cases of carcinoma of bronchus in males, 35 of carcinoma of stomach in males, and 38 of carcinoma of breast, the latter two including the extra cases (Table 4).
It is seen (Table 4) that the distribution of cases by numbers of asbestos bodies, which indicate the severity of asbestos exposure, does not show any striking difference between those in the overall series and those in carcinoma of bronchus or stomach or breast. There is no evidence of higher numbers of asbestos bodies in these carcinoma cases in spite of the higher prevalence of asbestos positive cases in carcinoma stomach and carcinoma breast.

Analysis was then made (Table 5) of the age distribution of the population, both total and cases of carcinoma of bronchus, stomach, and breast, the latter two including the extra cases.

It is seen (Table 5) that the peak age incidence of men and women in the overall series was the decade $61-70,35.5 \%$ men and $27.5 \%$ women. Women over 70 formed a higher proportion of the female population $(25.9 \%)$ than men over 70 in the male population $(16.3 \%)$. The age distribution in carcinoma bronchus shows a raised incidence in the decade 61 to 70 of $51.0 \%$. A higher proportion of males with carcinoma of stomach are in the older age groups. The peak age incidence of patients with carcinoma of breast (51-60) is a decade younger than the women in the overall series. 
TABLE 2

Distribution of Cases According to Sex, Main Disease, and

Prevalence of Asbestos Bodies

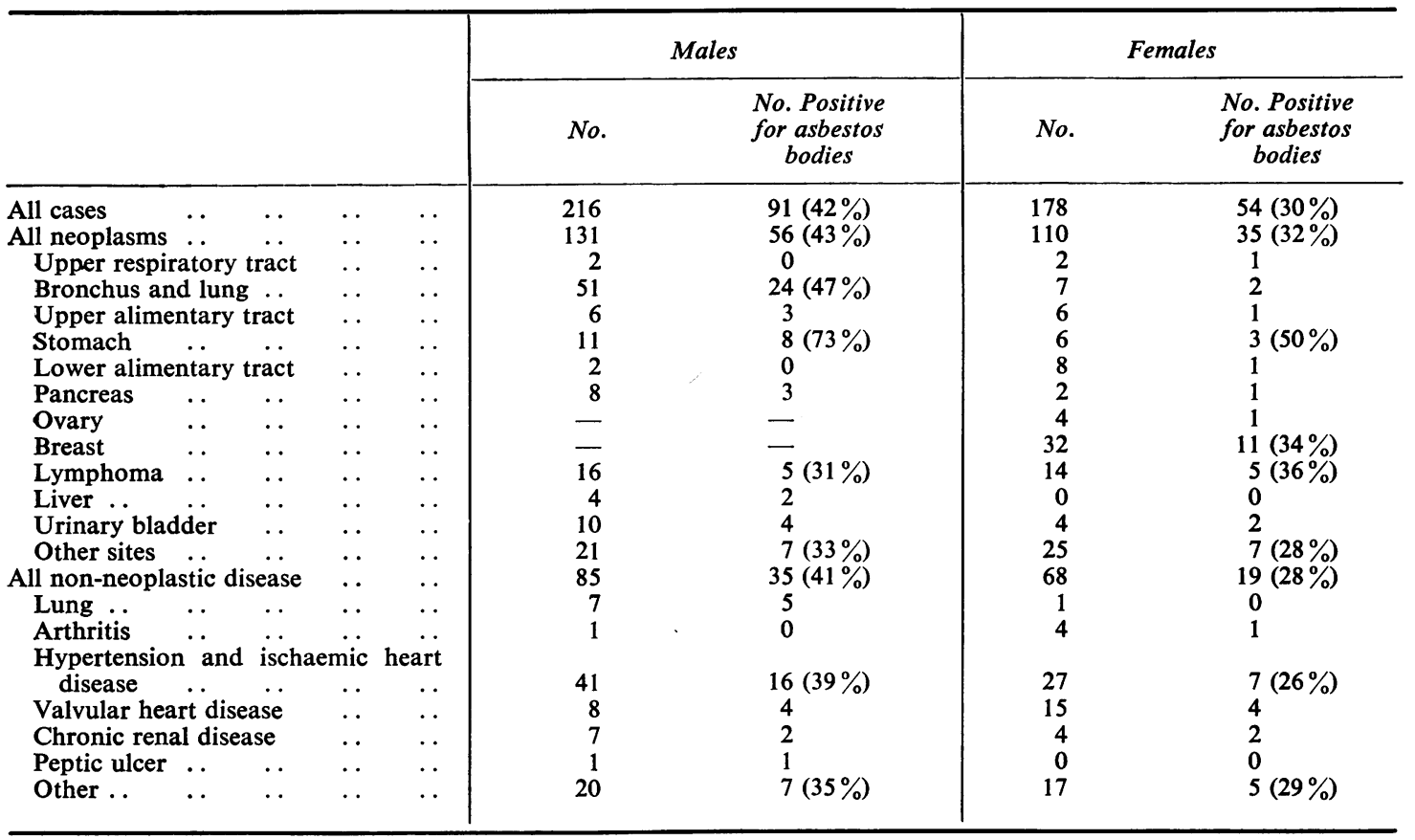

TABLE 3

INCIDENCE OF Asbestos Bodies in MALes With Carcinoma of StOMACH and Females With Carcinoma of Breast

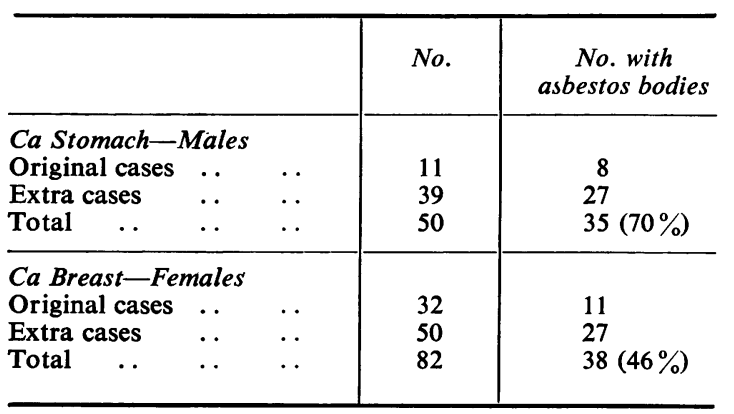

The prevalence of asbestos bodies in the overall series according to age is given in Table 6.

The incidence of asbestos positive cases is maximal in both sexes in the 41-50 age group (56\% in males, $42 \%$ in females) and then shows a moderate fall in the over 70 group.

From the data in Table 6 it was possible to calculate the expected incidence of asbestos positive cases in the groups of cancer patients, taking into consideration their age distribution (Table 7) for comparison with the actual incidence observed. The figure for expected incidence was derived in each age group by multiplication of the percentage asbestos positives in the overall patients by the number of patients in the carcinoma subgroups, e.g., $38 \%$ of 1 case $=0.38 ; 40 \%$ of 5 cases $=2.00$.

TABLE 4

Distribution of Numbers of Asbestos Bodies in Positive Cases of Carcinoma of Bronchus, Carcinoma of Stomach, and Carcinoma of Breast

\begin{tabular}{|c|c|c|c|c|}
\hline Males & \multicolumn{2}{|c|}{ Overall (91 cases) } & Ca Bronchus (24 cases) & Ca Stomach (35 cases) \\
\hline $\begin{array}{l}\text { No. of } \\
\text { asbestos bodies }\end{array}$ & $\begin{array}{c}1-5 \\
6-10 \\
11-20 \\
21+\end{array}$ & $\begin{array}{r}68.0 \% \\
12.1 \% \\
8.8 \% \\
11.0 \%\end{array}$ & $\begin{array}{r}70.8 \% \\
16.7 \% \\
8.3 \% \\
4.2 \%\end{array}$ & $\begin{array}{r}74.3 \% \\
11.4 \% \\
5.7 \% \\
8.6 \%\end{array}$ \\
\hline Females & \multicolumn{2}{|c|}{ Overall (54 cases) } & Ca Breast ( 38 cases) & \\
\hline $\begin{array}{l}\text { No. of } \\
\text { asbestos bodies }\end{array}$ & $\begin{array}{r}1-5 \\
6-10 \\
11-20 \\
21+\end{array}$ & $\begin{array}{r}83.3 \% \\
9.3 \% \\
3.7 \% \\
3.7 \%\end{array}$ & $\begin{array}{c}84.2 \% \\
10.5 \% \\
0 \\
5.3 \%\end{array}$ & \\
\hline
\end{tabular}


TABLE 5

Age Distribution in Carcinoma of Bronchus, STOMACH, AND BREAST

\begin{tabular}{|c|c|c|c|}
\hline Age & $\begin{array}{c}\text { Overall } \\
\text { cases } \\
(216 \text { men })\end{array}$ & $\begin{array}{l}\text { Ca Bronchus } \\
\text { (51 men) }\end{array}$ & $\begin{array}{l}\text { Ca Stomach } \\
(50 \text { men })\end{array}$ \\
\hline \multirow[t]{2}{*}{$\begin{array}{l}16-30 \\
31-40 \\
41-50 \\
51-60 \\
61-70 \\
71+\end{array}$} & $\begin{array}{r}3.7 \% \\
6.0 \% \\
11.5 \% \\
27.0 \% \\
35.5 \% \\
16.3 \%\end{array}$ & $\begin{array}{r}0 \% \\
2.0 \% \\
9.8 \% \\
27.5 \% \\
51.0 \% \\
9.8 \%\end{array}$ & $\begin{array}{l}0 \% \\
0 \% \\
2 \% \\
36 \% \\
54 \% \\
8 \%\end{array}$ \\
\hline & $100.0 \%$ & $100.0 \%$ & $100 \%$ \\
\hline Age & \multicolumn{2}{|c|}{$\begin{array}{c}\text { Overall } \\
\text { cases } \\
(178 \text { women })\end{array}$} & $\begin{array}{c}\text { Ca Breast } \\
(82 \text { women })\end{array}$ \\
\hline \multirow[t]{2}{*}{$\begin{array}{r}16-30 \\
31-40 \\
41-50 \\
51-60 \\
61-70 \\
71+\end{array}$} & \multicolumn{2}{|c|}{$\begin{array}{r}3.4 \% \\
5.1 \% \\
13.5 \% \\
24.7 \% \\
27.5 \% \\
25.9 \%\end{array}$} & $\begin{array}{r}0 \% \\
1.2 \% \\
22.0 \% \\
39.0 \% \\
26.8 \\
11.0 \%\end{array}$ \\
\hline & \multicolumn{2}{|c|}{$100.0 \%$} & $100.0 \%$ \\
\hline
\end{tabular}

TABLE 6

Asbestos Body Positivity aCCORDING to Age Distribution

\begin{tabular}{c|cc|cc}
\hline Age & Total & $\begin{array}{c}\text { No. +ve } \\
\text { for asbestos } \\
\text { men }\end{array}$ & $\begin{array}{c}\text { Todies } \\
\text { Total } \\
\text { women }\end{array}$ & $\begin{array}{c}\text { Nor asbestos } \\
\text { bodies }\end{array}$ \\
\hline $16-30$ & 8 & $0(0 \%)$ & 6 & $2(33 \%)$ \\
$31-40$ & 13 & $5(38 \%)$ & 9 & $1(11 \%)$ \\
$41-50$ & 25 & $14(56 \%)$ & 24 & $10(42 \%)$ \\
$51-60$ & 58 & $21(36 \%)$ & 44 & $12(27 \%)$ \\
$61-70$ & 77 & $37(48 \%)$ & 49 & $17(35 \%)$ \\
$71+$ & 35 & $14(40 \%)$ & 46 & $12(26 \%)$ \\
\hline Total & 216 & $91(42 \%)$ & 178 & $54(30 \%)$ \\
\hline
\end{tabular}

The findings in Table 7 show no excess of patients positive for asbestos bodies in carcinoma of bronchus, 24 observed against $22 \cdot 7$ expected. In males with carcinoma of stomach there is a marked excess of observed over expected: 35 against 21.6 (P < 0.005 ). In women with carcinoma of breast there is also a marked excess of observed over expected: 38 against $26.35(\mathrm{P}<0.025)$.

\section{Pleural plaques}

These were noted to be present in 21 men and four

TABLE 7

Observed and EXPeCted Asbestos Body InCidence in CARCinoma of Bronchus, Stomach, AND Breast

\begin{tabular}{|c|c|c|c|c|c|c|c|}
\hline \multirow{3}{*}{$\frac{\text { Males }}{\text { Age }}$} & \multirow{3}{*}{$\begin{array}{c}\text { Overall series } \\
\begin{array}{c}\text { Asbestos body } \\
+v e\end{array}\end{array}$} & \multicolumn{3}{|c|}{ Carcinoma of bronchus } & \multicolumn{3}{|c|}{ Carcinoma of stomach } \\
\hline & & \multirow{2}{*}{$\begin{array}{l}\text { No. of } \\
\text { cases }\end{array}$} & \multicolumn{2}{|c|}{ No. +ve for asbestos bodies } & \multirow{2}{*}{$\begin{array}{l}\text { No. of } \\
\text { cases }\end{array}$} & \multicolumn{2}{|c|}{ No. +ve for asbestos bodies } \\
\hline & & & Observed & Expected & & Observed & Expected \\
\hline \multirow[t]{2}{*}{$\begin{array}{r}31-40 \\
41-50 \\
51-60 \\
61-70 \\
71+\end{array}$} & $\begin{array}{l}38 \% \\
56 \% \\
36 \% \\
48 \% \\
40 \%\end{array}$ & $\begin{array}{r}1 \\
5 \\
14 \\
26 \\
5\end{array}$ & $\begin{array}{r}0 \\
3 \\
6 \\
13 \\
1\end{array}$ & $\begin{array}{r}0 \cdot 38 \\
2 \cdot 80 \\
5 \cdot 04 \\
12 \cdot 48 \\
2 \cdot 00\end{array}$ & $\begin{array}{r}0 \\
1 \\
18 \\
27 \\
4\end{array}$ & $\begin{array}{r}0 \\
0 \\
13 \\
18 \\
4\end{array}$ & $\begin{array}{r}0 \\
0.56 \\
6 \cdot 48 \\
12 \cdot 96 \\
1 \cdot 60\end{array}$ \\
\hline & & 51 & 24 & $22 \cdot 70$ & 50 & 35 & $21 \cdot 60$ \\
\hline \multirow{2}{*}{$\begin{array}{l}\text { Females } \\
\text { age } \\
\text { group }\end{array}$} & \multirow{2}{*}{$\begin{array}{c}\text { Overall series } \\
\text { asbestos body } \\
+v e\end{array}$} & \multirow{2}{*}{$\begin{array}{l}\text { No. of } \\
\text { cases }\end{array}$} & \multicolumn{2}{|c|}{$\overbrace{\text { No. }+ \text { ve for asbestos bodies }}^{\text {for }}$} & & & \\
\hline & & & Observed & Expected & & & \\
\hline \multirow[t]{2}{*}{$\begin{array}{l}31-40 \\
41-50 \\
51-60 \\
61-70 \\
71+\end{array}$} & $\begin{array}{l}11 \% \\
42 \% \\
27 \% \\
35 \% \\
26 \%\end{array}$ & $\begin{array}{r}1 \\
18 \\
32 \\
22 \\
9\end{array}$ & $\begin{array}{r}0 \\
8 \\
16 \\
11 \\
3\end{array}$ & $\begin{array}{l}0 \cdot 11 \\
7 \cdot 56 \\
8 \cdot 64 \\
7 \cdot 70 \\
2 \cdot 34\end{array}$ & & & \\
\hline & & 82 & 38 & $26 \cdot 35$ & & & \\
\hline
\end{tabular}


TABLE 8

Smoking Habits and Prevalence of Asbestos Bodies

\begin{tabular}{|c|c|c|c|c|c|c|c|c|c|c|}
\hline \multirow{2}{*}{\multicolumn{4}{|c|}{ Smoking }} & & \multirow{2}{*}{$\begin{array}{c}\text { Total } \\
\text { no. of } \\
\text { men }\end{array}$} & \multicolumn{2}{|c|}{ Asbestos body +ve } & \multirow{2}{*}{$\begin{array}{l}\text { Total } \\
\text { no. of } \\
\text { women }\end{array}$} & \multicolumn{2}{|c|}{ Asbestos body +ve } \\
\hline & & & & & & $N o$ & $\%$ & & $\mathrm{No}$ & $\%$ \\
\hline $\begin{array}{l}\text { Unknown } \\
\text { Never . . } \\
<10 \text { cigarettes } \\
10+\text { cigarettes } \\
\text { No. of cigarett } \\
\text { Pipe or cigar }\end{array}$ & $\begin{array}{l}\text {. } \\
\text { daily } \\
\text { daily } \\
\text { tes not } \\
\text {. }\end{array}$ & $\begin{array}{l}\ldots \\
\ldots \\
\ldots \\
\ldots \\
\text { specifi } \\
\ldots\end{array}$ & $\begin{array}{c}\ldots \\
\ldots \\
\cdots \\
\text { ed } \\
\ldots\end{array}$ & $\begin{array}{l}\cdots \\
\ldots \\
\cdots \\
\cdots \\
\ldots\end{array}$ & $\begin{array}{r}31 \\
20 \\
29 \\
119 \\
7 \\
10\end{array}$ & $\begin{array}{r}16 \\
11 \\
13 \\
45 \\
2 \\
4\end{array}$ & $\begin{array}{l}51 \cdot 6 \\
55 \cdot 0 \\
44 \cdot 8 \\
37 \cdot 8 \\
28 \cdot 5 \\
40 \cdot 0\end{array}$ & $\begin{array}{r}44 \\
69 \\
16 \\
45 \\
4 \\
0\end{array}$ & $\begin{array}{r}13 \\
20 \\
8 \\
12 \\
1 \\
0\end{array}$ & $\begin{array}{c}29 \cdot 5 \\
29 \cdot 0 \\
50 \cdot 0 \\
26 \cdot 7 \\
25 \cdot 0 \\
0\end{array}$ \\
\hline
\end{tabular}

women and absent in 49 men and 36 women. There was no record of either presence or absence of pleural plaques in the remaining cases of the overall series. Pulmonary asbestos bodies were present in 16 of the 21 men with pleural plaques $(76 \%)$ and in all four women $(100 \%)$, confirming the known association of pleural plaques with exposure to asbestos (Meurman, 1966). Among the patients recorded as having no pleural plaques, asbestos bodies were present in 17 of the 49 men $(35 \%)$ and in nine of the 36 women $(25 \%)$.

\section{Smoking}

Smoking habits were recorded in 185 of the 216 men and in 134 of the 178 women. The findings are given in Table 8.

The findings in Table 8 show no evidence of any increased incidence of asbestos bodies in smokers versus non-smokers in men, nor greater incidence in heavy cigarette smokers versus light smokers in either sex. The $50 \%$ incidence of positive cases in women who smoked less than 10 cigarettes daily is not statistically significant; $P$ is $>0.2$ in comparison with both the group of non-smokers and the group of heavy smokers.

The smoking habits were recorded in 50 of the 51 men with carcinoma of bronchus; 48 (96\%) of them were smokers, and $39(78 \%)$ smoked more than 10 cigarettes daily. These findings show the expected excess over men in the series as a whole, of whom $89.2 \%$ were smokers and $64 \%$ smoked more than 10 cigarettes daily. Table 9 shows that within the group of heavy smokers with carcinoma of bronchus the incidence of asbestos body positives of $49 \%$ is higher than the $38 \%$ found in the overall men who were heavy smokers. But the distribution of grades of numbers of asbestos bodies was similar in these two groups.

TABLE 9

Smoking Habits and Asbestos Bodies in All Men and Men with CARCINOMA OF BRONCHUS

\begin{tabular}{|c|c|c|c|c|c|}
\hline \multirow{2}{*}{\multicolumn{2}{|c|}{ Smoking habit }} & \multirow[b]{2}{*}{ All men } & \multirow{2}{*}{$\begin{array}{l}\text { Men with } \\
\text { ca bronchus }\end{array}$} & \multicolumn{2}{|c|}{$\begin{array}{c}\text { Percent asbestos }+ \text { ve in each } \\
\text { smoking group }\end{array}$} \\
\hline & & & & All men & Men with ca bronchus \\
\hline $\begin{array}{l}\text { Never } \\
<10 \text { cigarettes daily } \\
10+\text { daily } . \\
\text { Not specified } \\
\text { Pipe or cigar }\end{array}$ & $\begin{array}{l}\cdots \\
\cdots \\
\cdots \\
\cdots\end{array}$ & $\begin{array}{rr}20 & (11 \%) \\
29 & (16 \%) \\
119 & (64 \%) \\
7 & (4 \%) \\
10 & (5 \%)\end{array}$ & $\begin{array}{rr}2 & (4 \%) \\
4 & (8 \%) \\
39 & (78 \%) \\
1 & (2 \%) \\
4 & (8 \%)\end{array}$ & $\begin{array}{l}55 \\
45 \\
38 \\
29 \\
40\end{array}$ & $\begin{array}{r}100 \\
50 \\
49 \\
0 \\
25\end{array}$ \\
\hline Total & .. & $185(100 \%)$ & $50(100 \%)$ & & \\
\hline
\end{tabular}

\begin{tabular}{c|cc}
\hline $\begin{array}{c}\text { No. of } \\
\text { asbestos bodies }\end{array}$ & $\begin{array}{c}\text { All men smoking } \\
10+\text { cigarettes daily }\end{array}$ & $\begin{array}{c}\text { Ca bronchus men smoking } \\
\text { 10+ cigarettes daily }\end{array}$ \\
\hline $1-5$ & $25(56 \%)$ & $12(63 \%)$ \\
$6-10$ & $9(20 \%)$ & $4(21 \%)$ \\
$11-20$ & $5(11 \%)$ & $2(10 \%)$ \\
$21+$ & $6(13 \%)$ & 1 \\
$(5 \%)$
\end{tabular}


Occupation and industry, men

The occupation given in the first page of the clinical notes was sometimes unrecorded, sometimes noted as 'retired', and when stated tended to be the last job held. However, in many cases the student's notes proved more helpful, giving the patient's full occupational life-history, occasionally in great detail. In preference to recording a long and varied list of occupations we found it more practical to draw up a small list of descriptive terms to indicate the type of occupation, e.g., heavy manual, clerical. It also proved feasible to categorize the industry in which the patients worked, i.e., shipping, building, electrical, engineering, transport, furniture and other. Electrical and engineering were combined under one heading. Where a patient's occupational history involved changes, we selected the job and industry in which he had worked for the longest time. The following are examples:

\begin{tabular}{|c|c|c|}
\hline Docker & Heavy manual & Shipping \\
\hline Platelayer & Heavy manual & Transport \\
\hline Blacksmith & Heavy manual & $\begin{array}{r}\text { Electrical and } \\
\text { engineering }\end{array}$ \\
\hline Bricklayer & Heavy manual & Building \\
\hline Brewer's drayman & Heavy manual & Other \\
\hline Carpenter & Light manual & Building \\
\hline Cabinet-maker & Light manual & Furniture \\
\hline Cook & Light manual & Other \\
\hline Fitter's mate & Light manual & $\begin{array}{r}\text { Electrical and } \\
\text { engineering }\end{array}$ \\
\hline Bus & Ligh & Transport \\
\hline Gre & Light manual & Other \\
\hline
\end{tabular}

Tally clerk in docks Clerical Shipping Insurance clerk Clerical Other Student Clerical Other

\section{Occupation and industry, women}

The clinical records, including students' notes, contained less detail of occupation than the men's records. The most common occupation recorded was housewife. However, any patient noted to have worked outside the home in her earlier years or to have worked part-time or full-time after marriage was categorized according to occupation, i.e., light manual or clerical. Most working women kept to a single type of occupation. The following are examples of light manual: dress machinist, cleaner, shop assistant, storekeeper, packer, cook, nurse. Examples of clerical are: typist, wages clerk, secretary, civil servant, student, newspaper reporter. One woman, an unemployed epileptic, was classified as 'other'. The industries in the proforma were designed to fit the men. As a result most of the women's industries did not fit the main classifications and were categorized as 'other'. This heading included housewives, cleaners, shop assistants, cooks, typists, seamstresses, waitresses, leather makers, nurses, and workers in light industries who carried out various jobs such as bottle-sorting, cardboard box making, and tailors' machinists.

The findings are summarized in Table 10.

Table 10 shows a marked increase in asbestos body positives in men employed in heavy manual occupa-

TABLE 10

Asbestos Positivity in Relation to Occupation and Industry

\begin{tabular}{|c|c|c|c|c|c|}
\hline & & No. of men & $\begin{array}{c}\text { No. of men } \\
\text { asbestos }+v e\end{array}$ & No. of women & $\begin{array}{l}\text { No. of women } \\
\text { asbestos }+v e\end{array}$ \\
\hline $\begin{array}{l}\text { Occupation } \\
\text { Unknown ... } \\
\text { Heavy manual } \\
\text { Light manual } \\
\text { Clerical .. } \\
\text { Housewife .. } \\
\text { Other } \quad . .\end{array}$ & $\begin{array}{ll}. . & . \\
. . & . \\
. . & . \\
. . & . \\
. . & . \\
. . & . .\end{array}$ & $\begin{array}{r}10 \\
23 \\
144 \\
39 \\
- \\
-\end{array}$ & $\begin{array}{r}4(40 \%) \\
14(60.9 \%) \\
68(47 \cdot 2 \%) \\
5(12 \cdot 8 \%)\end{array}$ & $\begin{array}{r}16 \\
57 \\
17 \\
87 \\
1\end{array}$ & $\begin{array}{r}4(25 \%) \\
20(35 \%) \\
7(41 \%) \\
23(26 \%) \\
0(0 \%)\end{array}$ \\
\hline Total & .. & 216 & 91 & 178 & 54 \\
\hline 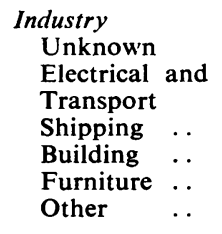 & \begin{tabular}{cc}
\multicolumn{2}{c}{ engineering } \\
.. &. \\
. &. \\
. &. \\
. &. \\
. &. \\
&.
\end{tabular} & $\begin{array}{r}32 \\
39 \\
26 \\
23 \\
18 \\
6 \\
72\end{array}$ & $\begin{array}{r}13(41 \%) \\
22(56 \%) \\
14(54 \%) \\
14(61 \%) \\
8(44 \%) \\
3(50 \%) \\
17(24 \%)\end{array}$ & $\begin{array}{r}29 \\
3 \\
\frac{1}{1} \\
1 \\
144\end{array}$ & $\begin{array}{r}12(41 \%) \\
1(33 \%) \\
0 \quad(0 \%) \\
0(0 \%) \\
41(28 \%)\end{array}$ \\
\hline Total & $\ldots$ & 216 & 91 & 178 & 54 \\
\hline
\end{tabular}


tions and in men in the shipping industry. Other industries associated with an increase in asbestos body positives are transport, and electrical and engineering. A striking finding is the low incidence $(12.8 \%)$ of asbestos body positives in men with a clerical occupation. This even applies to clerical occupations within the shipping, transport, and electrical and engineering industries. Thus of seven male clerks in these industries, only one was positive for asbestos bodies. This did not apply to the women with a clerical occupation, $41 \%$ of whom were asbestos body positive.

Examples of cases in men with $21+$ asbestos bodies were restricted to the shipping, building, and electrical and engineering industries. There were two women with $21+$ asbestos bodies, both recorded as housewives.

\section{Domiciliary address}

In the proforma (Fig. 1) the addresses given in the patient's notes were classified according to the postal numbers, i.e., E1 to E18, or named districts, e.g., Barking, Ilford, etc., and, finally, Rest of Essex, Rest of London, and Others. Among the Others were patients living elsewhere in Britain, mostly from the home counties and visitors from abroad. It turned out that 108 of the 216 males lived in $E$ numbered districts ranging from one in E18 to 12 in E6. There were 11 in Barking, 20 in Dagenham, 19 in Ilford, 9 in Romford, 27 in the Rest of Essex, 12 in the Rest of London, and 10 Others. In view of the comparatively small numbers per postal district we decided to group the districts into a few large areas when looking for any geographical association with incidence of asbestos bodies. In a comparison of an arrangement of three large areas running parallel from south to north with three large areas running

TABLE 11

Prevalence of Asbestos Body Positives aCCording to Domiciliary Area

\begin{tabular}{c|c|c|c|c}
\hline $\begin{array}{c}\text { Domiciliary } \\
\text { address }\end{array}$ & No. & $\begin{array}{c}\text { No. asbestos } \\
\text { body +ve }\end{array}$ & No. & $\begin{array}{c}\text { No. asbestos } \\
\text { body +ve }\end{array}$ \\
\hline Area 1 & 86 & $46(53 \%)$ & 62 & $28(45 \%)$ \\
2 & 72 & $27(37 \%)$ & 72 & $\begin{array}{c}19(26 \%) \\
6(20 \%)\end{array}$ \\
3 & 48 & $14(28 \%)$ & 30 & \\
\hline & 206 & & 164 & \\
\hline
\end{tabular}

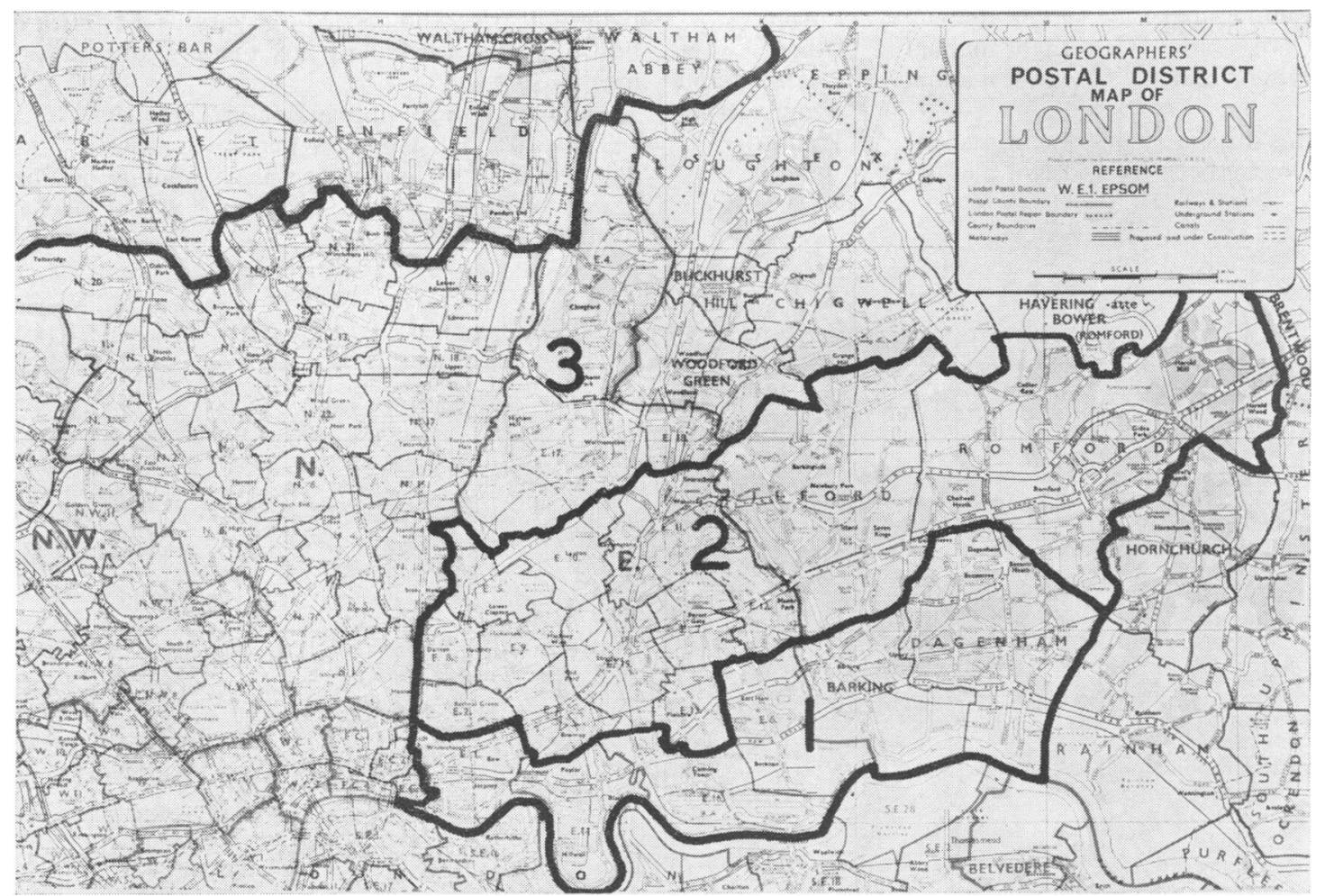

FIG. 3. Map of London showing the Areas 1, 2, and 3 used for comparison of prevalence of asbestos bodies in the necropsy population. Prevalence of asbestos bodies was highest in patients living in Area 1, lowest in Area 3. (Crown Copyright reserved-Reproduced by permission of Geographers' A-2 Map Co. Ltd.) 
parallel from west to east, we found that the latter grouping brought out greater differences in incidence of asbestos positive cases. The findings are shown in Table 11. Area 1, which comprises E1, 6, 13, 14, 16, Barking, and Dagenham, runs adjacent to the Thames and therefore includes the residential areas of dockland. Area 2, separated from dockland by Area 1, comprises E2, 3, 5, 7, 8, 9, 10, 11, 12, 15, Ilford, and Romford and includes semi-urban as well as urban residential districts. Area 3 comprises E4, 17, 18, Rest of Essex, and Rest of London and includes a fair number of rural addresses. The Areas are shown on a map (Fig. 3). The clinical notes did not record how long the patient had lived at the address stated or in the same district. The 10 males and 14 females who lived outside these Areas have been excluded from all the following tables.

It is seen in Table 11 that there is a marked correlation in incidence of asbestos body positives with domiciliary address. Residence in an urban address near the Thames is associated with twice the number of positive cases in both sexes than in a more rural one well away from the hospital. In fact the incidence in women of Area $1(45 \%)$ is higher than that for men of Area $2(37 \%)$. Having found previously (Table 10) that there was some correlation between occupation and industry and the incidence of asbestos bodies, we now analysed the data to see whether there was any trend for a similar correlation with domiciliary address, e.g., do a greater proportion of heavy manual workers tend to live in Area 1 than light manual workers or clerks?
It is seen in Table 12 that among men a higher proportion (42\%) lived in Area 1 than Area 2 $(35 \%)$ whereas among women a higher proportion $(44 \%)$ lived in Area 2 than Area 1 (38\%). Further, that men in occupations and industries associated with a raised incidence of asbestos bodies (Table 10) tend to live preferentially in Area 1 . Thus $61 \%$ of heavy manual workers, $54 \%$ of workers in the electrical and engineering industries, and $62 \%$ of combined shipping workers and building workers lived in Area 1 compared with $44 \%$ of light manual workers and only $18 \%$ male clerical workers. It is noteworthy that none of the 23 heavy manual workers lived in Area 3 in contrast to 12 of the 34 male clerical workers $(35 \%)$. The women clerical workers showed a different proportionate grouping from the male clerical workers; a higher proportion, 7 out of 17, lived in Area 1, a lower proportion, 4 out of 17, in Area 3. It is interesting to note that this correlates with the much higher incidence of asbestos body positives, 7 out of 17 , in female clerical workers than the 6 out of 34 in the male clerical workers.

In view of the finding that more industrial workers live in Area 1 than in Areas 2 or 3 the question arises whether their incidence of asbestos bodies varies according to domiciliary address. The incidence of asbestos body positives in workers in transport, shipping, building, and electrical and engineering added together and compared to domiciliary address is shown in Table 13.

Table 13 concerned with occupations within heavy

TABLE 12

Distribution of OcCupations and Industries in the DomiciliaRy Areas

\begin{tabular}{|c|c|c|c|c|c|c|c|c|}
\hline \multirow{3}{*}{$\begin{array}{c}\begin{array}{c}\text { Domiciliary } \\
\text { area }\end{array} \\
1 \\
2 \\
3\end{array}$} & \multirow{2}{*}{$\begin{array}{l}\text { Total } \\
\text { males }\end{array}$} & \multicolumn{3}{|c|}{ Occupation } & \multicolumn{4}{|c|}{ Industry } \\
\hline & & $\begin{array}{c}\text { Heavy } \\
\text { manual }\end{array}$ & $\begin{array}{l}\text { Light } \\
\text { manual }\end{array}$ & Clerical & Transport & Shipping & $\begin{array}{l}\text { Elect. }+ \\
\text { eng. }\end{array}$ & Building \\
\hline & $\begin{array}{ll}86 & (42 \%) \\
72 & (35 \%) \\
48 & (23 \%)\end{array}$ & $\begin{aligned} 14 & (61 \%) \\
9 & (39 \%) \\
0 & \end{aligned}$ & $\begin{array}{ll}61 & (44 \%) \\
44 & (32 \%) \\
34 & (24 \%)\end{array}$ & $\begin{aligned} 6 & (18 \%) \\
16 & (47 \%) \\
12 & (35 \%)\end{aligned}$ & $\begin{aligned} 8 & (33 \%) \\
10 & (42 \%) \\
6 & (25 \%)\end{aligned}$ & $\begin{aligned} 15 & (65 \%) \\
5 & (22 \%) \\
3 & (13 \%)\end{aligned}$ & $\begin{aligned} 21 & (54 \%) \\
11 & (28 \%) \\
7 & (18 \%)\end{aligned}$ & $\begin{aligned} 10 & (59 \%) \\
5 & (29 \%) \\
2 & (12 \%)\end{aligned}$ \\
\hline Total & $206(100 \%)$ & $23(100 \%)$ & $139(100 \%)$ & $34(100 \%)$ & $24(100 \%)$ & $23(100 \%)$ & $39(100 \%)$ & $17(100 \%)$ \\
\hline \multirow{2}{*}{$\begin{array}{c}\text { Domiciliary } \\
\text { area }\end{array}$} & \multirow{2}{*}{$\begin{array}{c}\text { Total } \\
\text { females }\end{array}$} & \multicolumn{3}{|c|}{ Occupation } & & & & \\
\hline & & $\begin{array}{c}\text { Light } \\
\text { manual }\end{array}$ & Clerical & Housewife & & & & \\
\hline $\begin{array}{l}1 \\
2 \\
3\end{array}$ & $\begin{array}{ll}62 & (38 \%) \\
72 & (44 \%) \\
30 & (18 \%)\end{array}$ & $\begin{aligned} 19 & (37 \%) \\
25 & (49 \%) \\
7 & (14 \%)\end{aligned}$ & $\begin{array}{ll}7 & (41 \%) \\
6 & (35 \%) \\
4 & (24 \%)\end{array}$ & $\begin{array}{ll}29 & (36 \%) \\
36 & (45 \%) \\
15 & (19 \%)\end{array}$ & & & & \\
\hline Total & $164(100 \%)$ & $51(100 \%)$ & $17(100 \%)$ & $80(100 \%)$ & & & & \\
\hline
\end{tabular}


TABLE 13

Incidence of Asbestos Body Positives in the Heavy Industries in RELATION TO BOTH OCCUPATION AND DOMICILIARY AREA

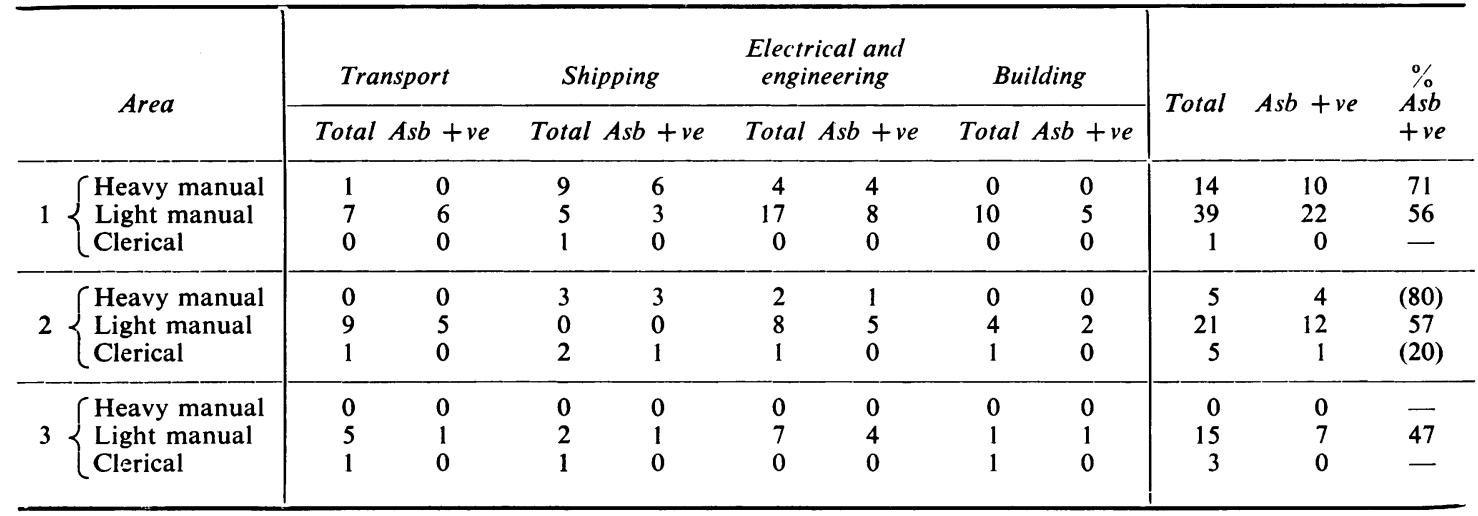

industries shows that the incidence of asbestos bodies is not affected by domiciliary area. Thus, light manual workers in shipping, electrical and engineering, and building demonstrate an approximate $50 \%$ asbestos positivity in all areas. Transport workers are exceptional, however, in that the incidence of asbestos positives falls from 6 in 7 in Area 1, to 5 in 9 in Area 2, to 1 in 5 in Area 3. Further breakdown of the nature of their work showed that bus drivers were all asbestos positive and that lorry drivers were mostly asbestos negative regardless of their domiciliary area. In general, though locally high atmospheric pollution may have played a part in the increased positives in Area 1, compared with reduced atmospheric pollution in the lower proportion of positives in Area 3, consideration of the findings in light manual workers in other heavy industries (Table 13) suggests that occupation and industry may be more important factors than domiciliary area in exposure to asbestos.

The severity of exposure to asbestos in positive cases was analysed in relation to domiciliary address (Table 14).

It is seen in Table 14 that there were proportionately more cases with high asbestos body counts in Area 1 in both males and females. Thus 11 of 46 males $(24 \%)$ in Area 1 had more than 10 asbestos bodies per $1.5 \mathrm{~cm}^{2}$ of lung section in contrast to 4 of $27(15 \%)$ males in Area 2 and 2 of $14(14 \%)$ males in Area 3. The four such cases among the females were confined to Area 1 . None occurred in females living in Areas 2 and 3.

TABLE 14

Comparison of Distribution of Numbers of Asbestos Bodies in Patients living in the 3 Domiciliary Areas

\begin{tabular}{|c|c|c|c|c|c|c|c|c|}
\hline \multirow{2}{*}{$\begin{array}{l}\text { Asbestos } \\
\text { bodies }\end{array}$} & \multicolumn{2}{|c|}{$\begin{array}{c}\text { Combined } \\
\text { areas }\end{array}$} & \multicolumn{2}{|c|}{ Area 1} & \multicolumn{2}{|c|}{ Area 2} & \multicolumn{2}{|c|}{ Area 3} \\
\hline & No. & $\%$ & No. & $\%$ & No. & $\%$ & No. & $\%$ \\
\hline $\begin{array}{l}\text { Males } \\
1-5 \\
6-10 \\
11-20 \\
21+\end{array}$ & $\begin{array}{r}59 \\
11 \\
8 \\
9\end{array}$ & $\begin{array}{r}68 \\
13 \\
9 \\
10\end{array}$ & $\begin{array}{r}28 \\
7 \\
5 \\
6\end{array}$ & $\begin{array}{l}63 \\
15 \\
10 \\
12\end{array}$ & $\begin{array}{r}22 \\
1 \\
2 \\
2\end{array}$ & $\begin{array}{l}80 \\
(4) \\
(8) \\
(8)\end{array}$ & $\begin{array}{l}9 \\
3 \\
1 \\
1\end{array}$ & $\begin{array}{r}64 \\
(22) \\
(7) \\
(7)\end{array}$ \\
\hline Total & 87 & 100 & 46 & 100 & 27 & 100 & 14 & 100 \\
\hline $\begin{array}{c}\text { Females } \\
1-5 \\
6-10 \\
11-20 \\
21+\end{array}$ & $\begin{array}{r}42 \\
5 \\
2 \\
2\end{array}$ & $\begin{array}{r}82 \\
(10) \\
(4) \\
(4)\end{array}$ & $\begin{array}{r}21 \\
3 \\
2 \\
2\end{array}$ & $\begin{array}{r}75 \\
11 \\
7 \\
7\end{array}$ & $\begin{array}{r}18 \\
1 \\
0 \\
0\end{array}$ & $\begin{array}{c}95 \\
(5) \\
(0) \\
(0)\end{array}$ & $\begin{array}{l}3 \\
1 \\
0 \\
0\end{array}$ & $\begin{array}{r}(75) \\
(25) \\
(0) \\
(0)\end{array}$ \\
\hline Total & 51 & 100 & 28 & 100 & 19 & 100 & 4 & 100 \\
\hline
\end{tabular}


TABLE 15

Distribution of Domiciliary Area in Males with Carcinoma of Stomach and in Females With Carcinoma of Breast

\begin{tabular}{|c|c|c|c|c|c|c|c|c|}
\hline \multirow{2}{*}{$\begin{array}{c}\begin{array}{c}\text { Domiciliary } \\
\text { area }\end{array} \\
1 \\
2 \\
3\end{array}$} & \multicolumn{2}{|c|}{ Overall men } & \multicolumn{2}{|c|}{ Males Ca stomach } & \multicolumn{2}{|c|}{ Overall women } & \multicolumn{2}{|c|}{ Women Ca breast } \\
\hline & $\begin{array}{l}86 \\
72 \\
48\end{array}$ & $\begin{array}{l}42 \% \\
35 \% \\
23 \%\end{array}$ & $\begin{array}{l}21 \\
18 \\
10\end{array}$ & $\begin{array}{l}43 \% \\
37 \% \\
20 \%\end{array}$ & $\begin{array}{l}62 \\
72 \\
30\end{array}$ & $\begin{array}{l}38 \% \\
44 \% \\
18 \%\end{array}$ & $\begin{array}{l}29 \\
37 \\
13\end{array}$ & $\begin{array}{l}37 \% \\
47 \% \\
16 \%\end{array}$ \\
\hline & 206 & $100 \%$ & 49 & $100 \%$ & 164 & $100 \%$ & 79 & $100 \%$ \\
\hline
\end{tabular}

Data were available in 38 men of both home address and address at work. The majority, 27, lived and worked in the same Area, i.e., 12 out of 15 in Area 1, 6 out of 11 in Area 2, and 9 out of 12 in Area 3. Among the total of 11 who lived and worked in different areas there were four asbestos body positives. This proportion fits the expected incidence whether calculated for home address or work address; a much larger number of cases would be required to show any preferential correlation with incidence of asbestos bodies.

Data were available in $\mathbf{4 0}$ women of the husband's occupation. Sixteen lived in Area 1, of whom seven were asbestos body positive ( $44 \%$ ) compared with the overall incidence of $45 \%$ of women in Area 1 . Twenty-four lived in Area 2, of whom eight were asbestos body positive $(33 \%)$ compared with the overall incidence of $26 \%$ of women in this group. The incidence of asbestos positives in this sample of 40 women was therefore typical of the overall findings in women. Of the nine asbestos body positive women in Areas 1 and 2, only three were married to men in industries likely to expose them to asbestos. Three of the nine asbestos negative women in group 1, and two of the 16 asbestos negative women in Area 2 were married to men in industries likely to expose them to asbestos. These findings do not show any positive correlation between industrial asbestos exposure of husbands and the presence of asbestos bodies in their wives.
The only patients with disease processes associated with excess incidence of asbestos bodies were those with carcinoma of stomach or carcinoma of breast (Tables 2 and 3). We therefore analysed the possibility that these particular patients might show a different domiciliary pattern from the remainder to account for their raised asbestos body positives, i.e., were mostly resident in Area 1 . In fact it is seen in Table 15 that the distribution of home addresses among both groups of patients is remarkably similar to that of the overall series.

Table 16 shows an analysis of the extra 48 women living in Areas 1, 2, and 3 with carcinoma of breast in relation to marital status, parity, home address, and incidence of asbestos bodies.

The numbers are small but suggest a higher proportion of asbestos positives in single women in spite of their address being in Areas 2 and 3. It is also seen that women with carcinoma breast in Areas 2 and 3 show a higher incidence of asbestos positives than is found in the overall female population of the original series in these Areas (Table 15).

We were interested to sae if the increased proportion of asbestos positive cases in carcinoma of stomach or carcinoma of breast might be due partly to the patients' occupation or industry but found no evidence that a greater proportion of these patients were in industries or occupations associated with increased exposure to asbestos than in the overall population.

TABLE 16

Incidence of Asbestos Body Positives in Carcinoma of Breast according to Domiciliary Area, Marital Status, and Parity

\begin{tabular}{|c|c|c|c|c|c|c|}
\hline & & Total & $A s b+v e$ & Area 1 & Area 2 & Area 3 \\
\hline \multirow[t]{2}{*}{$\begin{array}{l}\text { Nullipara single } \\
\text { Nullipara married } \\
\text { Multipara }\end{array}$} & $\begin{array}{l}\ldots \\
\cdots \\
\ldots\end{array}$ & $\begin{array}{r}6 \\
11 \\
31\end{array}$ & $\begin{array}{r}4 \\
6 \\
17\end{array}$ & $\begin{array}{rr}0 & \\
7 & (4+v e) \\
13 & (8+v e)\end{array}$ & $\begin{aligned} 5 & (3+v e) \\
3 & (2+v e) \\
13 & (5+v e)\end{aligned}$ & $\begin{array}{l}1(1+v e) \\
1(4+v e)\end{array}$ \\
\hline & & 48 & 27 & $20(12+v e)$ & $21(10+v e)$ & $7(5+v e)$ \\
\hline
\end{tabular}




\section{Discussion}

Previous studies reviewed by Meurman (1966), cited by Selikoff and Hammond (1970), and additional studies by Thomson and Graves (1966), Roberts (1967), Ashcroft (1968), and Pooley, Oldham, Um, and Wagner (1970) have confirmed the widespread prevalence of pulmonary asbestos bodies in routine necropsy series of men and women in many countries, first demonstrated by Thomson, Kaschula, and MacDonald (1963) in Cape Town. The prevalence is greater in men than women and in town-dwellers compared with rural populations. It is much greater in towns with shipping industries, or asbestos factories, than in towns without asbestos industries and is well marked in rural populations in the vicinity of asbestos mines or mills. It is not possible to make quantitative comparisons between these series because different methods were employed, i.e., examination variously of sections or smears or fluid from lungs. The larger the volume of lung examined, the greater is the chance of detecting positive cases (Meurman, 1966). A number of authors suggest that the degree of environmental pollution by asbestos dust is such that examination of sufficient material per case would reveal asbestos bodies in almost $100 \%$ of the population. All necropsy series are highly selected and in this instance the choice of quantity of material examined is arbitrary. Aware of these limitations, our objective was an intraseries comparison of asbestos pollution with the hope that correlations might come to light, enumerated in the present results, some of which might be of general application.

In addition to confirming the higher incidence of asbestos bodies in the older age groups and in men, we found a grading in degree of prevalence: highest in inhabitants of heavy industrial urban, intermediate in light industrial and residential urban, and lowest in residential and rural districts. There were more positive cases in heavy manual than light manual workers. The highest incidence was seen in men who had worked in the shipping, transport, and electrical and engineering industries. Interpretation of the detailed findings suggests that each of the three factors, occupation, industry, and area of residence, contributed variously to the inhalation of asbestos fibres.

The addresses noted in the clinical records refer to the patients' last residence and do not necessarily indicate that he or she had lived there for many years. But the older residents of East London tend to stay in the same district even when their married children move to other areas. The recorded occupation of 'housewife' may often conceal an earlier temporary phase of industrial occupation. The population we are dealing with is mostly made up of people who had to go out to work at the first opportunity in order to help support themselves and the family. It is almost inconceivable that after leaving school at the age of 12 to 14 , some 40 to 60 years ago, the women of East London, now designated housewives, just stayed at home until marriage. It is also noteworthy that on questioning, these women tended to deny ever having worked in a factory because for them this carried a social slur. In fact one of our patients (not in this series) with pleural mesothelioma and numerous pulmonary asbestos bodies who denied ever doing factory work was traced by Dr. W. J. Smither from her birthdate and maiden name to have worked for a period many years previously in an asbestos factory. There were at least seven asbestos factories in Area 1 in those years apart from the numerous different industries in which asbestos is employed. It is likely therefore that some 'housewives' with numerous asbestos bodies might have inhaled the fibres at work rather than solely in the home or streets. It was common practice to employ unskilled girls and women to clean the hessian sacks in which the crude asbestos was imported (Smither, 1974).

Further, with regard to atmospheric pollution in our Area 1 it was customary, before the health hazards of asbestos fibres inhalation were appreciated, to leave asbestos dumps in the open exposed to the prevailing westerly winds (Smither, 1974). Moreover children used these dumps for their games, in particular for playing 'snowballs' (Smither, 1974). Further atmospheric pollution by asbestos must have occurred in the heavy bombing of dockland during the second world war. Another source to the housewife was inhalation of asbestos dust when cleaning the clothes of asbestos factory workers (Newhouse and Thompson, 1965). Comparison of the numbers of asbestos bodies per positive case in our selected series with numbers counted by us in patients suffering from asbestosis show a considerable difference. Whereas the majority of our positive patients had 1 to 5 bodies per $6.75 \mathrm{~mm}^{3}$ lung, patients with asbestosis give counts of at least 1000 . The highest count in our series was 145 bodies in a married woman aged 47 who denied ever having worked for a living, resided in Dagenham (Area 1), and died of carcinoma of breast. Of our total of 145 positive cases only 13 had counts of more than 20 asbestos bodies and of these only two, both housewives, had counts above 100 .

Our findings in an East London population confirm preliminary results recorded by Selikoff and Hammond (1970) in a similar study of 3000 consecutive necropsies in New York City. They found a $70 \%$ incidence of asbestos body positives in men employed in shipyards and in the building industry, a $50 \%$ incidence in other manual workers, $47 \%$ in 'white collar' workers, and $39 \%$ in females.

We could find no association between asbestos 
positivity and any of the different types of nonneoplastic disease. In the neoplastic diseases there was no correlation with carcinoma of bronchus. This negative finding fits the observation of Elmes, McCaughey, and Wade (1965), who found asbestos bodies in $20 \%$ of 100 necropsies of carcinoma of bronchus in Belfast, an incidence not significantly different from that in their control groups of 200 males. Similar conclusions may be drawn from the report of Enterline, de Coufle, and Henderson (1973), who studied the incidence of respiratory cancer in relation to occupational exposure to asbestos. They found that there was no direct relationship below an exposure of 125 million particles per cubic foot (mppcf)-years in contrast to 5.7 times the expected incidence of men exposed to 750 or more mppcf-years. Knox, Holmes, Doll, and Hill (1968) found that the increased mortality from carcinoma of bronchus in asbestos workers exposed before 1933 was reduced to the national average equivalent in workers entering the industry after 1933 when safety measures in the factories had become mandatory. Newhouse (1969) found that asbestos factory workers carrying out jobs with least exposure to the dust had no excess mortality from respiratory disease. The above observations together with ours imply that the degree of asbestos exposure found in our selected patients, producing small numbers of asbestos bodies per $6.75 \mathrm{~mm}^{3}$ lung tissue, does not show any direct association with carcinoma of bronchus. Cigarette smoking apart, the increased incidence of carcinoma of bronchus in urban as compared with rural populations is likely to be due to atmospheric pollutants other than asbestos dust.

Our finding of an increased incidence of asbestos bodies in male patients with carcinoma of stomach (35 observed as against 21.6 expected in a total of 50 cases) appears a direct relationship and could not be accounted for by increased exposure due to residential area, occupation, industry or age distribution. An increase in incidence of carcinoma of the gastrointestinal tract including stomach has been reported in heavily exposed asbestos workers by König (1960), Selikoff, Churg, and Hammond (1964), and Elmes and Simpson (1971). Our findings suggest that non-industrial environmental exposure to asbestos dust may be a pathogenic factor in carcinoma of the stomach. Exposure to asbestos would lead inevitably to some ingestion both directly and via pulmonary secretions. Merliss (1971) considered that asbestos fibre contaminated talc used as a coating for rice to be a possible carcinogenic factor associated with the high incidence of gastric carcinoma in Japan and Japanese residents in the USA.

Our most puzzling finding is the raised incidence of asbestos body positives in women with carcinoma of the breast -38 observed as against $26 \cdot 3$ expected out of a total of 82 cases. Again this did not appear specifically due to occupation, area of residence or age group. We are unable to think of any way by which a higher proportion of women with breast cancer and asbestos bodies might have been selected to die and undergo necropsy at The London Hospital. Since nulliparas are more liable than multiparas to develop breast cancer and are also more likely to work in industry, we wondered if this might account for the increased incidence of asbestos positives. However, we found the same order of percentage of positives in nulliparas $(59 \%)$ and multiparas (55\%) with breast cancer while 31 of the 48 women were multiparas. It is difficult to conceive of a mechanism of direct exposure of mammary tissue to asbestos fibre. One may speculate on the remote possibility of carriage of fine asbestos fibres via retrograde lymphatic flow from the lungs to the chest wall, but it seems very unlikely. Thomson (1970) points out that pleural plaques tend to be restricted to parietal pleura overlying the ribs and that they are histologically composed of collagen initially formed from extrapleural connective tissue. He suggests that thin sharp asbestos fibres pierce the lungs and penetrate the parietal pleura after which they are held up by the ribs but pass through the intercostal muscles. If his speculation is correct then it is conceivable that asbestos fibres might infiltrate mammary tissue by direct extension through the muscle coats of the chest wall and might play a local summating carcinogenic role in the pathogenesis of carcinoma of breast.

We are grateful to Mrs. M. Hewitt and Miss C. Nickols for considerable technical help, to Miss R. Cresswell and Miss L. Singer for secretarial help, to the Asbestos Research Council for a grant towards Miss R. Cresswell's salary, and to Dr. W. J. Smither for a discussion in which he gave us an account of various possible sources of asbestos exposure in East London over the past decades.

\section{References}

Ashcroft, T. (1968). Asbestos bodies in routine necropsies on Tyneside: a pathological and social study. British Medical Journal, 1, 614-618.

Elmes, P. C., McCaughey, W. T. E., and Wade, O. L. (1965). Diffuse mesothelioma of the pleura and asbestos. British Medical Journal, 1, 350-353.

_ and Simpson, J. C. (1971). Insulation workers in Belfast. 3. Mortality 1940-66. British Journal of Industrial Medicine, 28, 226-236.

Enterline, P., de Coufle, P., and Henderson, V. (1973). Respiratory cancer in relation to occupational exposures among retired asbestos workers. British Journal of Industrial Medicine, 30, 162-166.

Knox, J. F., Holmes, S., Doll, R., and Hill, I. D. (1968). Mortality from lung cancer and other causes among workers in an asbestos textile factory. British Journal of Industrial Medicine, 25, 293-303.

König, J. (1960). Über die Asbestose. Archiv für Gewerbepathologie und Gewerbehygiene, 18, 159-204. 
Merliss, R. R. (1971). Talc-treated rice and Japanese stomach cancer. Science, 173, 1141-1142.

Meurman, L. (1966). Asbestos bodies and pleural plaques in a Finnish series of autopsy cases. Acta Pathologica et Microbiologica Scandinavica, Supplement, no. 181.

Newhouse, M. L. (1969). A study of the mortality of workers in an asbestos factory. British Journal of Industrial Medicine, 26, 294-301.

- and Thompson, H. (1965). Mesothelioma of pleura and peritoneum following exposure to asbestos in the London area. British Journal of Industrial Medicine, 22, 261-269.

Pooley, F. D., Oldham, P. D., Um, C-H., and Wagner, J. C. (1970). The detection of asbestos in tissues. In Pneumoconiosis: Proceedings of the 3rd International Conference, Johannesberg, 1969, edited by H. A. Shapiro, pp. 108-116. Oxford University Press, Cape Town.

Roberts, G. H. (1967). Asbestos bodies in lungs at necropsy. Journal of Clinical Pathology, 20, 570-573.

Selikoff, I. J., Churg, J., and Hammond, E. C. (1964).
Asbestos exposure and neoplasia. Journal of the American Medical Association, 188, 22-26.

and Hammond, E. C. (1970). Asbestos bodies in the New York City population in two periods of time. In Pneumoconiosis: Proceedings of the 3rd International Conference, Johannesberg, 1969, edited by H. A. Shapiro, pp. 99-105. Oxford University Press, Cape Town.

Smither, W. J. (1974). Personal communication.

Thomson, J. G. (1970). The pathogenesis of pleural plaques. In Pneumoconiosis: Proceedings of the 3rd International Conference, Johannesberg, 1969, edited by H. A. Shapiro, pp. 138-141. Oxford University Press, Cape Town.

and Graves, W. M. (1966). Asbestos an urban air contaminant. Archives of Pathology, 81, 458-464.

Kaschula, R. O. C., and MacDonald, R. R. (1963). Asbestos as a modern urban hazard. South African Medical Journal, 37, 77-81.

Received for publication 29 April 1974.

Accepted for publication 13 June 1974. 